\title{
Epidemiological profile of women with breast cancer in a public hospital in the Federal District of Brazil
}

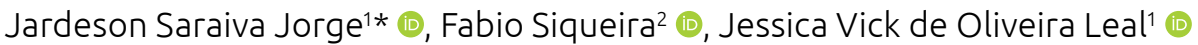

\section{ABSTRACT}

Introduction: In Brazil, for the 2020-2022 triennium, the estimated incidence of breast cancer in women was 66,280/year. It is the most incident type of cancer in all Brazilian regions. Several risk factors are associated with the probable etiology of breast cancer, though the complexity of the disease makes it difficult to define its main cause. Objective: To investigate the prevalence of factors associated with breast cancer in an outpatient population at a public hospital in the Federal District, and to verify the epidemiological profile of this population to compare the data obtained with data published in the literature. Method: This is a descriptive crosssectional study, with 115 participants diagnosed with breast cancer undergoing treatment in a highly complex unit of oncology care in the Federal District between July and October 2020. Data collection was done through a questionnaire. The electronic medical record was consulted to complement the data. Results: The majority of women were brown, married, with an average age of 52 . Hormone therapy was reported by $73.9 \%$, early menarche by only $33.9 \%$ and late menopause by $25.2 \%$. Most had children before the age of 30 and more than $80 \%$ breastfed. A family history of breast cancer was present in $30.4 \%$ of the sample. The consumption of alcoholic beverages was reported by more than half of the women, but the use of cigarettes was denied by the majority. The practice of some physical activity before the diagnosis of cancer was reported by $69.6 \%$. Most were overweight or had some degree of obesity. Nonspecial invasive carcinoma was the most common type. Conclusions: This study showed that the main factors present in the sample were: advanced age, alcohol consumption, use of hormone therapy and overweight.

KEYWORDS: breast neoplasms; risk factors; health profile; women's health.

\section{INTRODUCTION}

Breast cancer represents the most common malignant neoplasm in women worldwide and is also one of the most important causes of death in this gender ${ }^{1}$. In Brazil, the estimate of new cases of the disease in females for the triennium 2020-2022 is 66,280 per year, which places it as the most common type of cancer in all regions ${ }^{2}$.

For the Federal District, the estimate for the year 2020 is 730 new cases of this neoplasm in women, the second most common, second only to prostate cancer².

Although this disease occurs in all parts of the world, the incidence, mortality, and survival rates vary considerably between different regions of the world. The justification for these variations may lie in the different specificities of each population, such as population structure, lifestyle, genetic factors, environment, and health care ${ }^{1}$.

Several risk factors are associated with the probable etiology of breast cancer, though, due to the complexity of the disease, it is not yet possible to specifically define the main cause. However, the genetic inheritance of the BRCA-1 and BRCA-2 genes, which are associated with high risk for the development of familial breast cancer, is a good predictor of the genetic cause of cancer ${ }^{3}$.

The best known factors that can increase the possibility of breast malignancy include: gender, advanced age, early menarche and late-onset menopause, nulliparity, late primiparity, non-breastfeeding, sedentary lifestyle, obesity, exposure to estrogen (contraceptives and hormone replacement therapy for menopause), family history, genetic mutation, smoking, and alcohol consumption ${ }^{4,5}$.

The clinical stage presented by patients at the time of diagnosis is a determining factor in the design of the therapeutic management. Unfortunately, in developing countries, especially those where the majority of the population has low or middle income, most cases of breast cancer are diagnosed at advanced stages due to lack of knowledge or resources ${ }^{6}$.

${ }^{1}$ Programa Multiprofissional em Atenção ao Câncer da Escola Superior de Ciências da Saúde - Brasília (DF), Brazil. ${ }^{2}$ Hospital Regional de Taguatinga, Secretaria de Saúde do Distrito Federal - Taguatinga (DF), Brazil.

*Corresponding author: jardesonsaraiva@gmail.com

Conflict of interests: nothing to declare.

Received on: 04/01/2021. Accepted on: 05/21/2021. 
The objectives of this study were to investigate the prevalence of factors associated with breast cancer in women undergoing treatment at the outpatient clinic of clinical oncology of a tertiary hospital in the Federal District, to verify the epidemiological profile of this population and to compare the data obtained in this study with those in the literature.

\section{METHOD}

A descriptive cross-sectional study was carried out with 115 patients diagnosed with breast cancer who were undergoing treatment in a high-complexity oncology unit between July and October 2020.

Sample size was calculated using a tool available in the OpenEpi version 3.0 software. The 200 patients who underwent intravenous (IV) chemotherapy in 2019 at an outpatient level were considered, with a $95 \%$ confidence interval. Taking these values into account, the sample would need at least 110 patients in order to be representative.

For data collection, a questionnaire was applied in the form of an interview/anamnesis about socioeconomic aspects, risk, and protection factors that patients could or not have been exposed to during their lives. In order to have access to the histological type of breast cancer of the patient at the time of diagnosis and other information necessary for the study, the electronic medical record was consulted. Patients informed their consent to participate in the research by signing the Informed Consent.

The socioeconomic and epidemiological variables taken into account are: age, education, children, breastfeeding, weight and height (used to calculate the body mass index - BMI), family history, age at menarche, age at first pregnancy, use hormone therapy, physical activity, smoking, and alcohol consumption.

Inclusion criteria were: diagnosis of breast cancer, female patients, 18 years of age or more, having agreed to participate in the research, and signed informed consent. Patients disoriented in time and space, unaccompanied, who could not answer the questionnaire clearly, and patients with a history of a primary tumor other than breast cancer were excluded. In all, two patients were excluded by the first criterion.

Data were stored in Microsoft Office Excel ${ }^{\circledR} 2010$ spreadsheets, in which a database was built for descriptive analysis through the distribution of absolute and relative frequencies, in order to generate the results in the form of graphics and tables.

This study was approved by the Research Ethics Committee of Centro Universitário do Distrito Federal (UDF) via Plataforma Brasil (approval number: 4.115.051/2020).

\section{RESULTS}

Of the total of 115 patients who participated in the survey, the mean age was 52.8 years (ranging from 28 to 80 ), most declared themselves brown (55.7\%), 52.1\% had completed high school or high education degree, $38 \%$ were married, with a family nucleus composed of one to three people (67\%), family income around one to three minimum wages (41.7\%), and own housing conditions (61.7\%) (Table 1).

Most had their menarche in the age group considered as normal or late, and the use of contraceptives and/or hormone replacement therapies was reported by $73.9 \%$ of them. Mean age at first pregnancy was 23.5 years. Most women had menopause in the normal age group (Table 2).

More than $80 \%$ breastfed. Of them, $63.5 \%$ reported that they did it for a period equal to or longer than one year. Family history of breast cancer in up to fourth degree relatives was reported by $30.4 \%$ of the women in the study (Table 2).

Regarding alcoholism, smoking, and physical activity, the former was prevalent in $61.7 \%$. Smoking was prevalent in less than half of the participants (44.3\%). The majority (69.6\%) reported that they practiced some type of physical activity before the diagnosis of breast cancer.

To interpret the participants' BMI values, the World Health Organization (WHO) classification of nutritional status was used?

Most patients were overweight or had some degree of obesity at the time of the interview (Figure 1). In addition to some incomplete medical records, some patients were unable to inform their weight and height. Thus, $10.4 \%$ of patients did not have their BMI calculated.

The most prevalent histological type of tumors among the study participants was non-special invasive carcinoma. This type corresponded to $96.5 \%$ of the total diagnoses. The other types of cancer identified in the sample were invasive carcinomas, special types $(3.5 \%)$

\section{DISCUSSION}

The worldwide incidence of breast cancer in black women traditionally used to be lower than in white ones, though the disease was more aggressive. From 2012 to the present day, this reality has been changing and new cases of breast cancer have an almost similar distribution between white and black women ${ }^{8}$.

More than $50 \%$ of the women were 50 years old or older, with a mean age of 52.8 years. According to Instituto Nacional de Câncer José Alencar Gomes da Silva (INCA), the risk of cancer is increased in women after the age of 50 due to cumulative exposure to risk factors and biological alterations ${ }^{9}$. A study carried out in Bahia also showed a greater predominance of people aged 50 years old or older ${ }^{10}$.

Of the 115 participants in the present study, $73.9 \%$ reported having used hormonal therapy with contraceptives and/or hormone replacement for menopause at some point in their lives, which emerged as an important common risk factor in the population studied. A similar study in South Africa did not associate the use of hormone therapy with breast cancer ${ }^{6}$. The same was observed in Özsoy et al. ${ }^{11}$. 
Table 1. Socioeconomic data of women assisted in a high-complex oncology care unit. Brasilia, 2020.

\section{Characteristic}

$\mathbf{N}$

$\%$

Age range (years)

\begin{tabular}{|c|c|c|}
\hline$<30$ & 1 & 0.9 \\
\hline $30-39$ & 10 & 8.7 \\
\hline $40-49$ & 30 & 26 \\
\hline $50-59$ & 46 & 40 \\
\hline $60-69$ & 25 & 21.8 \\
\hline$>70$ & 3 & 2.6 \\
\hline Mean age & \multicolumn{2}{|c|}{52.8 years } \\
\hline \multicolumn{3}{|l|}{ Ethnicity } \\
\hline Yellow & 11 & 9.6 \\
\hline White & 25 & 21.7 \\
\hline Black & 13 & 11.3 \\
\hline Brown & 64 & 55.7 \\
\hline Did not declare & 2 & 1.7 \\
\hline \multicolumn{3}{|l|}{ Education } \\
\hline Illiterate & 4 & 3.5 \\
\hline Incomplete Elementary School & 34 & 29.6 \\
\hline Complete Elementary School & 10 & 8.7 \\
\hline Incomplete High School & 7 & 6.1 \\
\hline Complete High School & 32 & 27.8 \\
\hline Incomplete High Education & 7 & 6.1 \\
\hline Complete High Education & 16 & 13.9 \\
\hline Postgraduate studies & 5 & 4.3 \\
\hline \multicolumn{3}{|l|}{ Marital Status } \\
\hline Married & 44 & 38 \\
\hline Single & 19 & 17 \\
\hline Divorced & 40 & 35 \\
\hline Widower & 12 & 10 \\
\hline
\end{tabular}

Family Nucleus

\begin{tabular}{l|c|c}
\hline Alone & 10 & 8.7 \\
\hline 1-3 people & 77 & 67 \\
\hline 4-7 people & 28 & 24.3 \\
\hline
\end{tabular}

Family Income

\begin{tabular}{l|c|c}
\hline Less than 1 salary & 27 & 23.5 \\
\hline From 1 to 3 salaries & 48 & 41.7 \\
\hline From 3 to 6 salaries & 26 & 22.6 \\
\hline More than 6 salaries & 10 & 8.7 \\
\hline Did not know & 4 & 3.5 \\
\hline Housing Conditions & 41 & 35.7 \\
\hline Rent & 71 & 61.7 \\
\hline Owner & 3 & 2.6 \\
\hline Other &
\end{tabular}

Table 2. Biological and behavioral factors involved in the genesis of breast cancer in women treated at a highly complex oncology care unit. Brasilia, 2020.

\begin{tabular}{|l|l|l}
\hline Characteristics & N & $\%$
\end{tabular}

Age of Menarche (years)

\begin{tabular}{l|c|c}
\hline$\geq 9$ and $<10$ & 2 & 1.7 \\
\hline $10-12$ & 37 & 32.2 \\
\hline $13-15$ & 60 & 52.2 \\
\hline$>15$ & 13 & 11.3 \\
\hline Did not remembe & 3 & 2.6 \\
\hline $\begin{array}{l}\text { Use of contraceptives and/or } \\
\text { hormone replacement }\end{array}$ & & \\
\hline Yes & 85 & 73.9 \\
\hline No & 30 & 26.1
\end{tabular}

Age of first pregnancy (years)

\begin{tabular}{l|c|c}
\hline $15-17$ & 15 & 13.1 \\
\hline $18-21$ & 33 & 28.7 \\
\hline $22-25$ & 22 & 19.1 \\
\hline $26-29$ & 13 & 11.3 \\
\hline$\geq 30$ & 18 & 15.6 \\
\hline Nulliparas & 13 & 11.3 \\
\hline Did not know & 1 & 0.9 \\
\hline Breastfeeding & &
\end{tabular}

\begin{tabular}{c|c|c}
\hline Yes & 96 & 83.5 \\
\hline$>1$ year & 61 & 63.5 \\
\hline$<1$ year & 35 & 36.5 \\
\hline No & 19 & 16.5 \\
\hline
\end{tabular}

Age of Menopause (years)

\begin{tabular}{l|l|l}
\hline $45-49$ & 57 & 49.6 \\
\hline $50-60$ & 29 & 25.2 \\
\hline Does not apply & 29 & 25.2 \\
\hline
\end{tabular}

Neoplasm in the Family

\begin{tabular}{|c|c|c|}
\hline Yes & 79 & 68.7 \\
\hline \multicolumn{3}{|c|}{ Type of Cancer } \\
\hline Breast & 35 & 44.3 \\
\hline Ovary & 2 & 2.5 \\
\hline Others & 42 & 53.2 \\
\hline No & 36 & 31.3 \\
\hline
\end{tabular}

Alcoholism

\begin{tabular}{l|c|c}
\hline Former drinker & 66 & 57.4 \\
\hline Yes & 5 & 4.3 \\
\hline No & 44 & 38.3 \\
\hline
\end{tabular}

Smoking

\begin{tabular}{l|c|c}
\hline Former smoker & 46 & 40 \\
\hline Yes & 5 & 4.3 \\
\hline No & 64 & 55.7 \\
\hline
\end{tabular}

Practice of physical activity prior to diagnosis

\begin{tabular}{c|l|l}
\hline Yes & 80 & 69.6 \\
\hline No & 35 & 30.4 \\
\hline
\end{tabular}


In the "AMAZONA III" study, both in the group of women undergoing treatment in the private network and in the group receiving care from the public network, it was observed that more than half had undergone hormonal therapy during their lifetime ${ }^{12}$.

However, some studies claim that the risk of developing breast cancer influenced by contraceptive therapy and hormone replacement therapy can decrease or even zero over the years of its interruption. Sun et al. stated that after two years of discontinuation of contraceptives, the risk of developing cancer significantly decreases and, after 10 years, this correlation is null ${ }^{5}$.

Given this scenario, the best thing to be done is to guide patients who use hormone therapy to adopt preventive measures, to make periodic consultations with the mastologist, and to perform tests in the presence of any suspicious changes.

The Brazilian Society of Pediatrics considers, for women: precocious puberty those that start before the age of eight; late puberty as the ones that start after 13 years of age; and normal when it occurs between 8 and 13 years of age ${ }^{13}$. Rojas and Stuckey bring studies that showed early menarche as a risk factor for breast cancer, as this is the moment that starts ovulation cycles, which increase women's exposure to endogenous estrogen ${ }^{14}$.

None of the women in this study had menarche at an early age. Oliveira et al. observed most women with menarche in the normal age group ${ }^{15}$, corroborating the data found in the study by Santos et al. ${ }^{16}$.

Normal menopause occurs between the ages of 40 and 55 years. It is considered early when it occurs before 40 years of age and late after 55 years of age ${ }^{17}$.

The later the menopause occurs, the longer women are exposed to breast-stimulating hormones, estrogen and progesterone. A relative risk of two was found for developing breast cancer in women who went through menopause after age 55 compared to women who went through it before age $45^{14,18}$.

In the present study, only $25.2 \%$ of women reported menopause in the age group that includes cases considered late. A study from Paraná and another from Minas Gerais also did not observe a relationship between late menopause and the consulted cases $^{16,18}$.

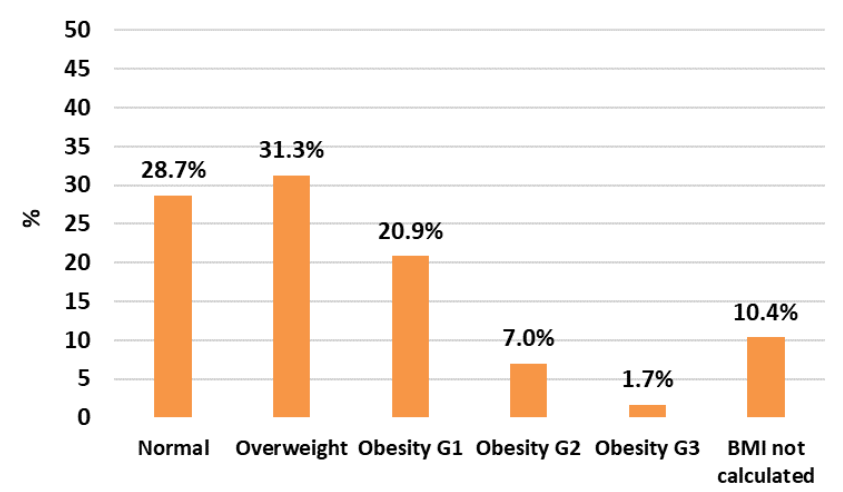

Figure 1. Classification of the participants' body mass index.
Primiparity after the age of 30 is associated with a higher risk of breast cancer, due to the likely cumulative exposure of these women to factors, cited in our study, which have the potential to change breast cells to a neoplastic configuration and which will be stimulated during pregnancy to proliferate. The relationship between nulliparity and the risk of malignant breast cancer is justified by the non-exposure to the benefits of breastfeeding, explained below ${ }^{19}$.

The majority of women in our study had their first pregnancy before the age of 30 years. A study from Pará showed a similar result ${ }^{17}$.

Breastfeeding is widely known for its protective potential against breast cancer due to the hypoestrogenic state during this period $^{14}$. This protection is provided both in the pre- and postmenopause period ${ }^{9}$. Breastfeeding for at least a year reduces the risk of developing breast cancer by $48 \%^{20}$.

In this study, $83.5 \%$ of the participating women reported having breastfed their children, most of them for a period equal to or longer than one year. Rosa et al..$^{12}$, as well as Rocha et al. ${ }^{18}$, also reported a high number of women who breastfed.

Regarding the family history of cancer as a risk factor, the literature states that having individuals diagnosed with breast and/or ovarian cancer in the family is related to a higher risk of developing the disease in the breast throughout life due to the hereditary nature of the disease. This risk triples for firstdegree relatives ${ }^{14}$.

In our data, $30.4 \%$ of the women reported having a case of breast cancer in a relative up to the fourth degree in their family. Rocha et al. ${ }^{18}$ and Nunes et al. ${ }^{21}$ reported a prevalence of breast cancer in the participants' relatives of less than $30 \%$, considering relatives up to the fourth and first degrees, respectively.

Alcohol consumption and its relationship with breast cancer is controversial, but most epidemiological studies demonstrate a consistent relationship between the daily consumption of at least $30 \mathrm{~g}$ of alcohol and breast cancer ${ }^{14}$. The consumption of this substance is related to the increase in the levels of hormones associated with estrogen, which trigger the pathway of its receptor ${ }^{5}$.

In our sample, alcohol consumption was reported by more than $60 \%$ of women, who reported no daily use, only social. Several similar studies did not show a correlation between alcohol consumption and the investigated cases ${ }^{10,12,18,19}$. However, a Brazilian survey showed alcohol consumption in $57 \%$ of the sample ${ }^{22}$, similar to the data in our study.

Recent studies have associated active and passive smoking with an increased risk of breast cancer and worse survival outcomes ${ }^{14}$. Mutagenic compounds from cigarette smoke have already been found in the breast fluid of non-lactating women, showing the potential for activating oncogenes in the breast through this habit ${ }^{5}$.

In our data and in several other studies, it was observed that most women denied exposure to smoking, generating little association of cases in these studies with smoking ${ }^{10,12,18,19,22}$. 
The regular practice of physical activity is a factor that is related to the protection of women against breast cancer. It is believed that the mechanism that leads to this protection is due to the decrease in body fat, with a consequent reduction in the peripheral conversion of androgens to estrogens by the aromatase enzyme ${ }^{5,14}$.

Most of the participants in our study reported doing some kind of physical activity before being diagnosed with cancer. However, $60.9 \%$ were overweight or had some degree of obesity at the time of the interview. Rocha et al. ${ }^{18}$, revealing data similar to those shown here, reported that more than $70 \%$ of the participants were overweight or had some degree of obesity, which shows that obesity is an important factor common to this population.

The most prevalent histological type of breast cancer in the population of this study was non-special type invasive carcinoma (96.5\%), but in a smaller quantity there were also special type invasive carcinomas (3.5\%). INCA estimates that invasive carcinoma of the non-special type corresponds to the most common type of breast cancer, representing between 70 and $80 \%$ of cases. Santos et al. ${ }^{16}$, Rocha et al. ${ }^{18}$, and Nunes et al. ${ }^{21}$ also showed a predominance of the non-special type in their studies.

\section{CONCLUSION}

This study showed that the main factors prevalent in the population with breast cancer studied were: advanced age, socially consuming alcohol, use of hormone therapy, and overweight.

The data emphasize the importance of medical follow-up with advancing age. Healthy routines and habits must also continue as breast cancer preventive practices, as well as the promotion of the rational use of hormonal therapies.

\section{ACKNOWLEDGMENTS}

To the hospital management and the director of the oncology clinic who authorized this study to be carried out.

\section{AUTHORS' CONTRIBUTIONS}

J.S.J.: Investigation, funding acquisition, investigation, data curation, methodology, project management, formal analysis, writing - review \& editing.

F.S.: Administration, supervision, writing - review \& editing. J.V.O.L.: writing — review \& editing.

\section{REFERENCES}

1. Momenimovahed Z, Salehiniya H. Epidemiological characteristics of and risk factors for breast cancer in the world. Breast Cancer. 2019;11:151-64. https://dx.doi. org/10.2147\%2FBCTT.S176070

2. Instituto Nacional de Câncer José Alencar Gomes da Silva. Estimativa 2020: incidência de câncer no Brasil. Rio de Janeiro: INCA; 2019.

3. Yanes T, Young MA, Meiser B, James PA. Clinical applications of polygenic breast cancer risk: a critical review and perspectives of an emerging field. Breast Cancer Res. 2020;22(1). https://doi. org/10.1186/s13058-020-01260-3

4. Diniz CSG, Pellini ACG, Ribeiro AG, Tedardi MV, Miranda MJ, Touso MM, et al. Breast cancer mortality and associated factors in São Paulo State, Brazil: an ecological analysis. BMJ Open. 2017;7(8):016395. https://doi.org/10.1136/bmjopen-2017-016395

5. Sun YS, Zhao Z, Yang ZN, Xu F, Lu HJ, Zhu ZY, et al. Risk Factors and Preventions of Breast Cancer. Int J Biol Sci. 2017;13(11):1387-97. https://doi.org/10.7150/ijbs.21635

6. KakudjiBK,MwilaPK,BurgerJR,DuPlessisJM.Epidemiological, clinical and diagnostic profile of breast cancer patients treated at Potchefstroom regional hospital, South Africa, 2012-2018: an open-cohort study. Pan African Med J. 2020;36:9. https:// dx.doi.org/10.11604\%2Fpamj.2020.36.9.21180

7. Nascimento MM, Pereira LGD, Cordeiro PRN, Araújo LMG. Comparação e concordância de critérios à classificação do IMC de idosas fisicamente ativas, residentes no Sertão Nordestino. J Hum Growth Dev. 2017;27(3):342-9. http://dx.doi. org/10.7322/jhgd.128227
8. Yedjou CG, Sims JN, Miele L, Noubissi F, Lowe L, Fonseca DD, et al. Health and Racial Disparity in Breast Cancer. Adv Exp Med Biol. 2019;1152:31-49. https://doi.org/10.1007/978-3-030-20301-6_3

9. Instituto Nacional de Câncer José Alencar Gomes da Silva. Fatores de risco para o câncer de mama [Internet]. Rio de Janeiro: INCA; 2019 [cited on September 3, 2020]. Available at: https://www.inca. gov.br/controle-do-cancer-de-mama/fatores-de-risco

10. Reis FP, Santos MEG, Sena WR, Santana R, Freitas TS, Silveira HF, et al. Perfil epidemiológico das pacientes com câncer de mama atendidas em uma unidade de saúde em São Francisco do Conde, Ba. Rev Ciênc Méd Biol. 2016;15(2):144-50.

11. Özsoy A, Barça N, Dölek BA, Aktas H, Elverice E, Araz L, et al. The Relationship Between Breast Cancer and Risk Factors: A Single-Center Study. Eur J Breast Health. 2017;13(3):145-9. https://doi.org/10.5152/tjbh.2017.3180

12. Rosa DD, Bines J, Werutsky G, Barrios CH, Cronemberger E, Queiroz GS, et al. The impact of sociodemographic factors and health insurance coverage in the diagnosis and clinicopathological characteristics of breast cancer in Brazil: AMAZONA III study (GBECAM 0115). Breast Cancer Res Treat. 2020;183(3):749-57. https://doi.org/10.1007/s10549-020-05831-y

13. PaulaLCC,Puñales M.PuberdadePrecoce[Internet].Brasil:Sociedade Brasileira de Pediatria, Departamento Científico de Endocrinologia; 2016 [cited on March 8, 2021]. Available at: https://www.sbp.com.br/ fileadmin/user_upload/2016/09/Puberdade-Precoce.Leila_Ve4_.pdf

14. Rojas K, Stuckey A. Breast Cancer Epidemiology and Risk Factors. Clin Obstet Gynecol. 2016;59(4):651-72. https://doi. org/10.1097/grf.0000000000000239 
15. Oliveira TSG, Neris RR, Santos LNT, Teixeira RG, Magnabosco P, Anjos ACY. Perfil de mulheres com câncer de mama tratadas com quimioterapia. Rev Enferm UFPE On Line. 2016;10(11):4097-103. https://doi.org/10.5205/1981-8963-vl0i1lal1496p4097-4103-2016

16. Santos JCM, Silva CM, Teixeira JJV, Peder LD. Perfil epidemiológico e clínico de mulheres com câncer de mama na região oeste do Paraná. Rev Bras Ciên Saúde. 2019;23(4):44958. https://doi.org/10.22478/ufpb.2317-6032.2019v23n4.44252

17. FederaçãoBrasileira deGinecologiae Obstetrícia(Febrasgo).Manual de Orientação em Climatério. Climatério: Conceitos, Etiopatogenia, Endocrinologia e Epidemiologia [Internet]. Brasil: Febrasgo [cited on March 8, 2021]. Available at: https://edisciplinas.usp.br/pluginfile. php/4236559/mod_page/content/3/Climaterio.pdf

18. Rocha FS, Silva WS, Nascimento ER, Bacciotti AM. Epidemiological profile of breast cancer in a reference hospital in the north region. Mastology. 2018;28(3):169-75. https://doi.or $\mathrm{g} / 10.29289 / 2594539420180000413$
19. Sousa MM, Figueredo SB, Fernandes RM. Perfil clínicoepidemiológico de mulheres com neoplasia de mama atendidas no hospital regional de referência no município de AraguaínaTO no período de 2000 a 2015. Desafios. 2016;2(2):283-306. https://doi.org/10.20873/uft.2359-3652.2016v2n2p283

20. Gradim CVC, Magalhães MC, Faria MCF, Arantes CIS. Aleitamento materno como fator de proteção para o câncer de mama. Rev Rene. 2011;12(2):358-64.

21. Nunes BAP, Siqueira SL, Pereira SM, Pacheco TJ, Pessanha TO, Mendonça SB. Perfil epidemiológico dos pacientes diagnosticados com câncer de mama em Campos dos Goytacazes (RJ), Brasil. Rev Bras Mastologia. 2012;22(4):117-23.

22. Souza NHA, Falcão LMN, Nour GFA, Brito JO, Castro MM, Oliveira MS. Câncer de mama em mulheres jovens: estudo epidemiológico no nordeste brasileiro. SANARE. 2017;16(2):60-7. https://doi.org/10.36925/sanare.v16i2.1179 